\title{
AN ASSESSMENT PROCESS FOR A CAPSTONE COURSE: DESIGN OF FLUID THERMAL SYSTEMS
}

\author{
William S. Janna, John I. Hochstein \\ Herff College of Engineering \\ The University of Memphis \\ Memphis TN 38152
}

\section{Extended Abstract}

An assessment process has been developed in order to measure how well a capstone design course, Design of Fluid Thermal Systems, meets the needs of the students with regard to process educational goals and educational objectives. The ultimate purpose of the process is to improve the quality of the capstone design course in the fluid-thermal systems area by obtaining feedback about the course from students who have completed it.

The process goals are to provide the students with the ability to: solve practical pipe flow problems; determine the pipe diameter that will minimize the initial and operating costs for an installation; tsize a pump for a given piping system and to select an operating configuration to avoid pump cavitation; demonstrate the ability to analyze a heat exchanger: given two flow streams, calculate expected outlet temperatures; and effectively function as a member of a design team.

With regard to the ABET a through k program outcomes, the students are expected to gain:

(c) the ability to design a system, component or process to meet needs

(d) the ability to function on multidisciplinary teams

(e) the ability to identify, formulate, and solve engineering problems

(g) the ability to communicate effectively

(k) the ability to use the techniques, skills, and tools in engineering practice

(o) An ability to work professionally in the thermal sciences area, including the ability to successfully design a fluid thermal system

The Instructor(s) of Record for the course will administer to the students enrolled in that course a survey designed to assess progress toward process goals, and to measure identified program outcomes. Information collected from this survey is summarized, evaluated, and used as a basis for defining action items.

An annual report will be produced to document the activities of each process cycle. The report shall include:

- $\quad$ A title page with the process title, the cycle number, and the period of performance.

- $\quad$ Documentation prepared by the instructor to record his findings.

- Documentation of the instructor's evaluation of the findings and consequent action items.

- $\quad$ A section containing the Process Definition for that cycle.

- An Appendix showing the activities performed during the current cycle and an estimate of the faculty time expended in performing those activities.

The annual report is provided in this study. 


\section{Fluid-Thermal Design Improvement Process \\ MECH 4314 \\ Design of Fluid Thermal Systems}

Fall 2003 Cycle

Period of Performance Fall 2003 Semester

Team Members

William S. Janna

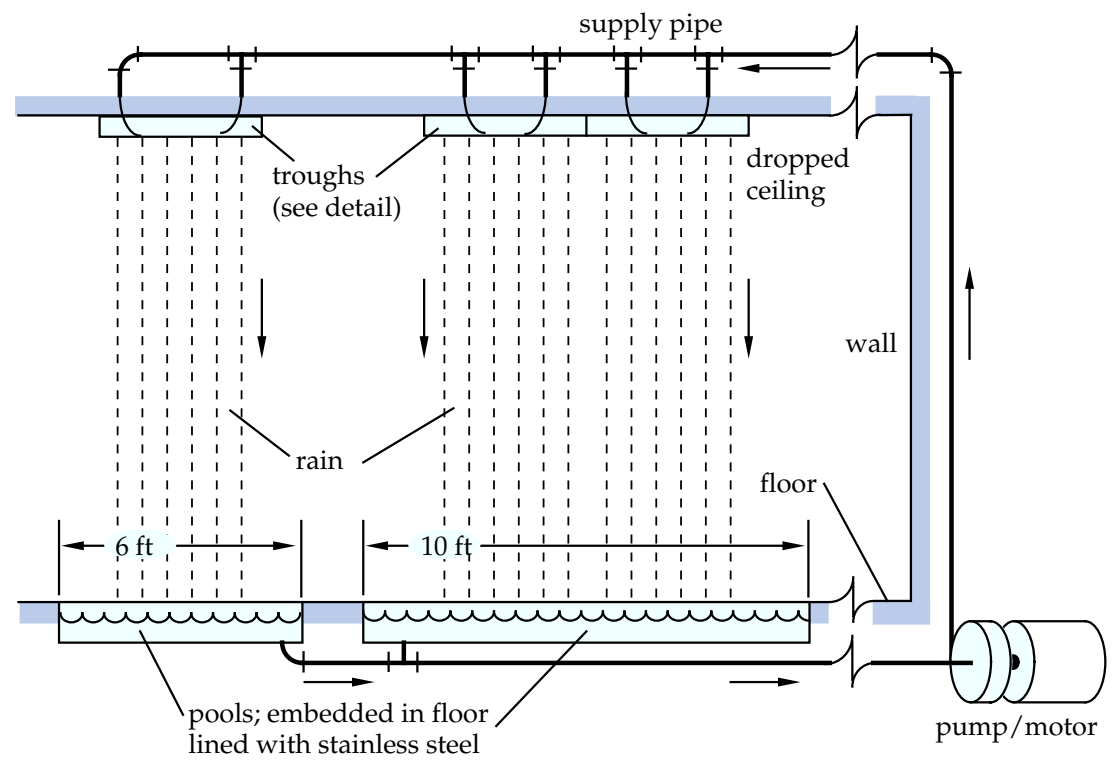

Table of Contents

General Information

Copy of Current Survey Instrument

Summary of Survey Results/Commentary

Design Considerations

Student Comments with Commentary

List of Action Items and Disposition

Estimate of Time Spent 


\section{Design of Fluid Thermal Systems \\ Capstone Design Course \\ Improvement Process Definition}

\begin{tabular}{|ll|}
\hline \multicolumn{1}{|c|}{ Process Summary } \\
\hline - & Version 1.1 \\
\hline - & process period: annual \\
\hline
\end{tabular}

\section{Process Purpose}

Improve the quality of the capstone design course in the fluid-thermal systems area by obtaining feedback about the course from students who have completed it.

\section{Process Goals}

- Students will be asked to demonstrate the ability to solve practical pipe flow problems: given a piping system, find the pressure drop.

- Students will be asked to demonstrate the ability to solve practical pipe flow problems: given minimal piping system information, determine the pipe diameter that will minimize the initial and operating costs for an installation.

- Students will be asked to demonstrate the ability to size a pump for a given piping system and to select an operating configuration to avoid pump cavitation.

- Students will be asked to demonstrate the ability to analyze a heat exchanger: given two flow streams, calculate expected outlet temperatures.

- Students will be asked to demonstrate the ability to function as a member of a design team. [This is evaluated by performance as part of a group while solving the semester long design project.]

\section{Program Educational Objectives Supported}

1. Graduates entering immediately into professional practice upon graduation are capable of performing duties of an entry-level engineering position.

2. Graduates pursuing graduate studies are capable of successfully completing an advanced degree.

3. Graduates recognize the need for and are capable of pursuing life-long learning.

This process directly supports PEO1 and PEO2, and indirectly supports PEO3.

\section{Program Outcomes Measured}

(c) the ability to design a system, component or process to meet needs

(d) the ability to function on multidisciplinary teams

(e) the ability to identify, formulate, and solve engineering problems

(g) the ability to communicate effectively

(k) the ability to use the techniques, skills, and tools in engineering practice

(o) An ability to work professionally in the thermal sciences area, including the ability to 
successfully design a fluid thermal system

\section{Process Description}

The Process Team shall be composed of the Instructor(s) of Record for MECH 4314, Design of Fluid Thermal Systems for the Fall semester. At the conclusion of the Fall semester, the Instructor(s) of Record for the course will administer to the students enrolled in that course a survey designed to assess progress toward the Process Goals, and to measure identified Program Outcomes. The information collected from this survey will be summarized, evaluated, and used as a basis for defining action items. If the action items are of limited scope, dealing with specifics of the course, the action item will be implemented immediately by the course instructor for the next semester. If the action item is broader in scope, to the extent that a decision to implement should be made by the entire program faculty, it will be brought to the attention of the Undergraduate Program Improvement Process Team Leader and then to a Department Faculty Meeting for discussion. After the completion of the Fall semester, the activities of the Process Team will be recorded in an annual activity report.

Process Milestones

(Flow Chart following)

\begin{tabular}{l|l}
\hline \hline Date & \multicolumn{1}{c}{ Task } \\
\hline \hline August & Review status of action items from previous cycle \\
\hline Nov/Dec & Administer survey in MECH 4314 \\
\hline January & $\begin{array}{l}\text { Evaluate results; compose list of action items; produce list of appropriate } \\
\text { actions for disposition. }\end{array}$ \\
\hline January & Consult faculty on action items that need faculty input; proceed as indicated \\
\hline January & Resolve action items as appropriate \\
\hline January & Document process, produce report, present results at faculty meeting. \\
\hline \hline
\end{tabular}

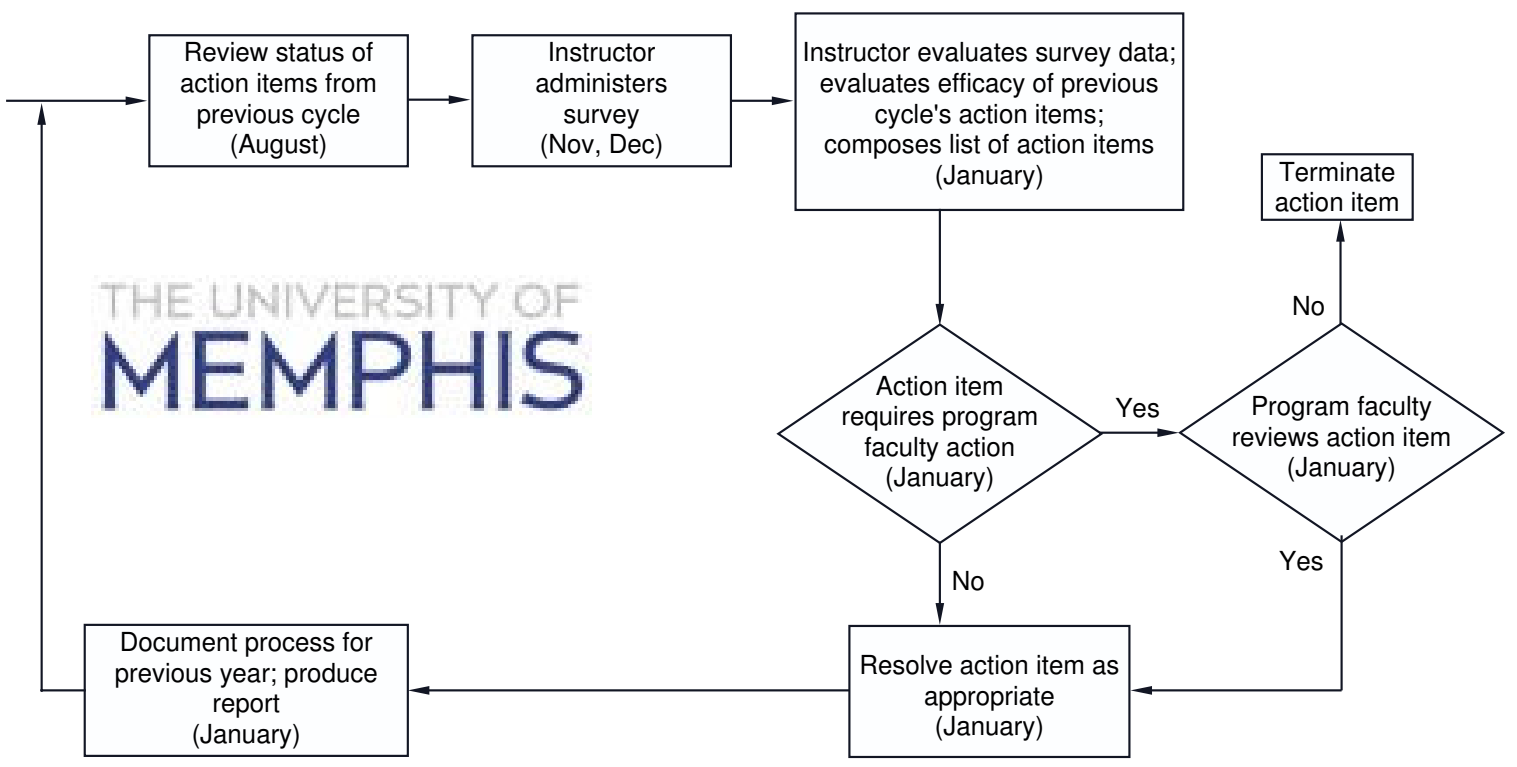

Fluid Thermal Systems Capstone Design Course Improvement Process

Proceedings of the 2004 American Society for Engineering Education Annual Conference and Exposition Copyright (C) 2004, American Society for Engineering Education 


\section{Process Documentation}

An annual report will be produced to document the activities of each process cycle. At a minimum, that report shall include:

- A title page with the process title, the cycle number, and the period of performance.

- Documentation prepared by the instructor to record his findings.

- Documentation of the instructor's evaluation of the findings and consequent action items.

- A section containing the Process Definition for that cycle.

- An Appendix showing the activities performed during the current cycle and an estimate of the faculty time expended in performing those activities.

This documentation shall be kept on file by the instructor until it is needed.

\section{Process Definition History}

\begin{tabular}{|c|l|c|}
\hline Version & \multicolumn{1}{|c|}{ Description } & Date \\
\hline 1.1 & Updated PEO's and PO's; added flow chart & April 2003 \\
\hline 1.0 & Version 1.0 survey administered to class & December 2002 \\
\hline
\end{tabular}




\section{Current Survey Instrument}

\section{Department of Mechanical Engineering \\ Assessment of MECH 4314 \\ Design of Fluid Thermal Systems}

In an effort to make improvements in our program, I am requesting that you complete this survey. You are doing a great service and your help is sincerely appreciated. The survey offers you the opportunity to express your true feelings about what you learned in Design of Fluid Thermal Systems as well as how the course was managed.

So please be as liberal with criticism and as generous with praise as you deem appropriate. Your anonymous responses will be tabulated for subsequent review after this semester has ended. The compiled data will serve as a guide for purposes of proposing modifications to and improvements of the course. Hopefully, the changes will benefit current and future undergraduates. Thank you very much for participating in this survey.

Completed surveys will be compiled onto a blank copy, and the originals (i.e., those filled out by students in their own handwriting) will be discarded. Your comments will remain confidential.

You are asked to sign this cover sheet so that a record can be kept that you did complete this form. The cover sheet will be removed and discarded after final grades are turned in.

Please print name

Title of Your Project 


\section{Fall 2003 Student Assessement of MECH 4314 Design of Fluid Thermal Systems}

To the student: The Department of Mechanical Engineering has established Program Objectives and corresponding measures to determine if we have achieved these objectives. By completing this questionnaire, you will be helping to determine whether this course satisfies certain criteria that are important to your overall education. Please evaluate the educational quality of this course by responding to the following statements according to:

$\mathbf{s a}=$ strongly agree $; \mathbf{a}=$ agree $; \mathbf{a d}=$ neither agree nor disagree $; \mathbf{d}=$ disagree $; \mathbf{s d}$ strongly disagree

\section{Program Objectives}

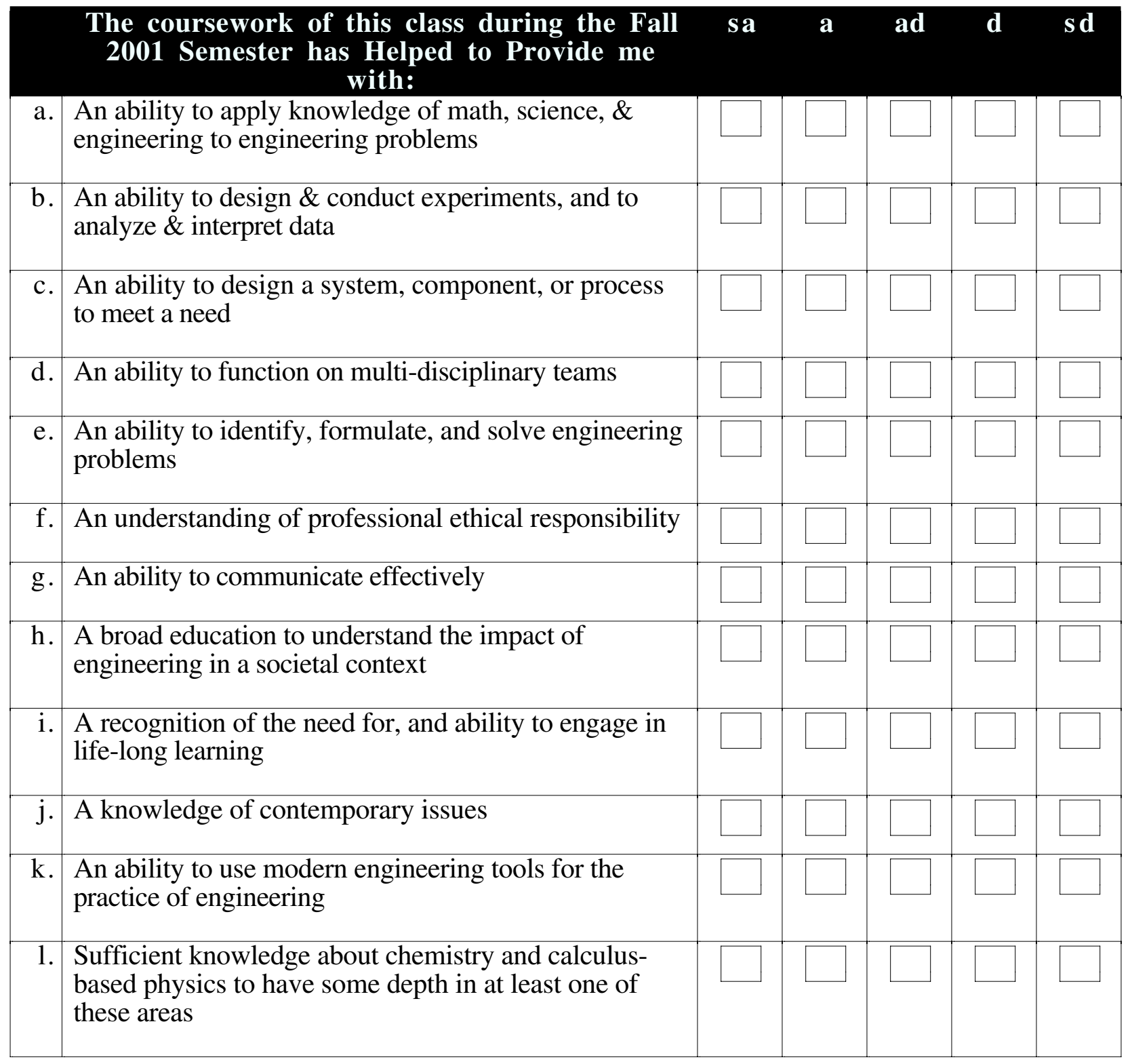




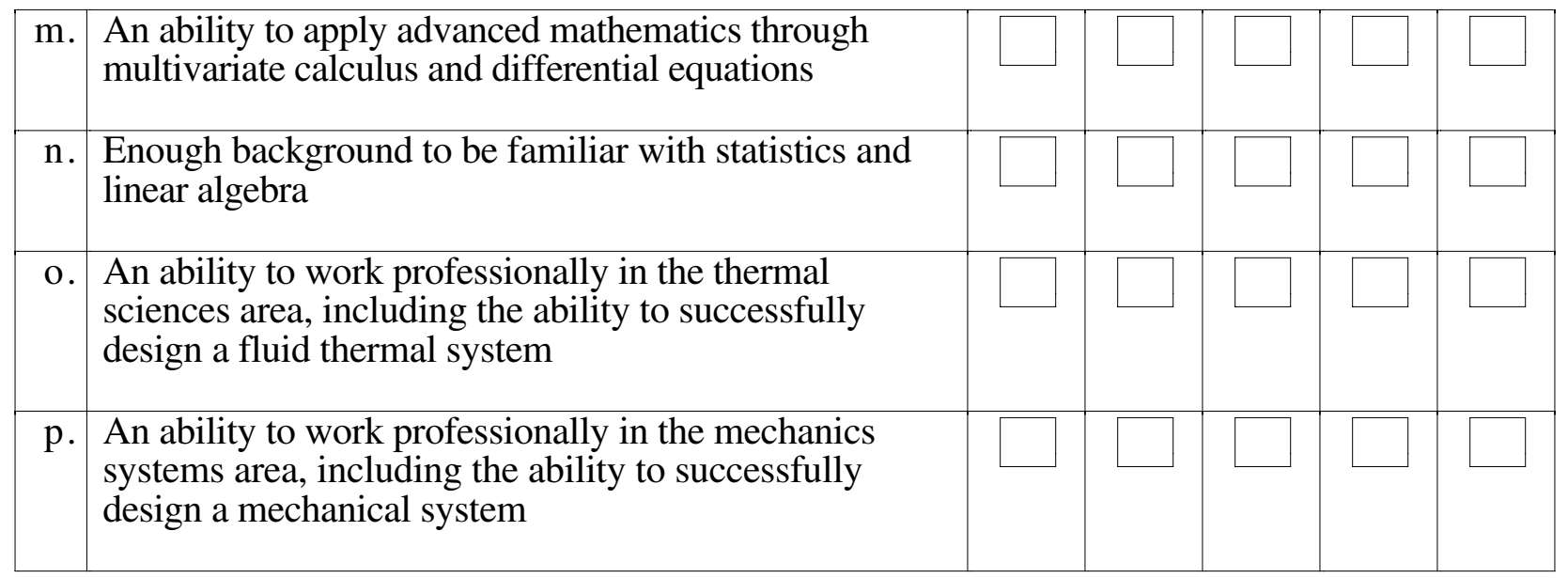

\section{Competency Areas}

All courses in the Mechanical Engineering Curriculum have Competency Areas associated with them. In this course, there are 5 areas that have been identified as competency areas. These are as follows:

1. Demonstrate the ability to solve practical pipe flow problems: given a piping system, find the pressure drop.

2. Demonstrate the ability to solve practical pipe flow problems: given minimal piping system information, determine the pipe diameter that will minimize the initial and operating costs for an installation.

3. Demonstrate the ability to size a pump for a given piping system and to select an operating configuration to avoid pump cavitation.

4. Demonstrate the ability to analyze a heat exchanger: given two flow streams, calculate expected outlet temperatures.

5. Demonstrate the ability to function as a member of a design team. [This is evaluated by performance as part of a group while solving the semester long design project.]

\begin{tabular}{|c|c|c|c|c|c|c|}
\hline & First Four Competency Areas & $\mathbf{s a}$ & $\mathbf{a}$ & ad & d & sd \\
\hline a. & $\begin{array}{l}\text { These competencies were made clear to me at the } \\
\text { beginning of the semester. }\end{array}$ & & & & & \\
\hline b. & $\begin{array}{l}\text { I was tested on these competencies with } \\
\text { straightforward exams. }\end{array}$ & & & & & \\
\hline c. & $\begin{array}{l}\text { I had ample opportunity through multiple exams to } \\
\text { demonstrate that I had successfully mastered each } \\
\text { competency. }\end{array}$ & & & & & \\
\hline $\mathrm{d}$. & $\begin{array}{l}\text { My grades on the competency exams accurately reflect } \\
\text { the knowledge I gained in each area. }\end{array}$ & & & & & \\
\hline e. & $\begin{array}{l}\text { These competencies matched with what was taught in } \\
\text { the course. }\end{array}$ & & & & & \\
\hline
\end{tabular}


f. I fully approve of the practice of substituting the average of my grades on competency exams for a "Test I."

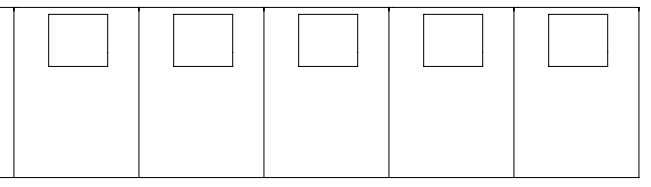

\section{Course Management}

\begin{tabular}{|c|c|c|c|c|c|c|}
\hline & Design of Fluid Thermal Systems & sa & $\mathbf{a}$ & ad & d & $\mathbf{s d}$ \\
\hline a. & $\begin{array}{l}\text { I liked using the internet to obtain course information } \\
\text { such as homework assignments, sample exams, etc. }\end{array}$ & & & & & \\
\hline b. & $\begin{array}{l}\text { I found using e-mail to correspond with the instructor } \\
\text { and with my classmates convenient. }\end{array}$ & & & & & \\
\hline c. & $\begin{array}{l}\text { I liked the practice of posting my group's name and } \\
\text { insignia on the internet. }\end{array}$ & & & & & \\
\hline d. & $\begin{array}{l}\text { Working on a design project helped me to develop my } \\
\text { "design creativity." }\end{array}$ & & & & & \\
\hline e. & I liked working in a group on a design project. & & & & & \\
\hline f. & $\begin{array}{l}\text { The course, Design of Fluid Thermal Systems, was } \\
\text { well managed. }\end{array}$ & & & & & \\
\hline
\end{tabular}

\section{Interacting with Freshmen}

\begin{tabular}{|c|c|c|c|c|c|c|}
\hline & Design of Fluid Thermal Systems & $\mathbf{s} \mathbf{a}$ & $\mathbf{a}$ & ad & d & sd \\
\hline a. & $\begin{array}{l}\text { Interacting with the freshmen was an academically } \\
\text { rewarding experience. }\end{array}$ & & & & & \\
\hline b. & $\begin{array}{l}\text { The freshmen were able to provide our group with } \\
\text { assistance/ideas. }\end{array}$ & & & & & \\
\hline c. & $\begin{array}{l}\text { The freshmen were able to participate actively in the } \\
\text { design process. }\end{array}$ & & & & & \\
\hline d. & $\begin{array}{l}\text { I believe I was able to positively influence the freshmen } \\
\text { to want to stay in engineering. }\end{array}$ & & & & & \\
\hline e. & $\begin{array}{l}\text { I had no difficulty in describing our project to the } \\
\text { freshmen. }\end{array}$ & & & & & \\
\hline f. & $\begin{array}{l}\text { By working with freshmen, I gained some appreciation } \\
\text { for the effort involved in managing engineers. }\end{array}$ & & & & & \\
\hline
\end{tabular}




\begin{tabular}{|r|l|l|l|l|l|l|}
\hline g. & $\begin{array}{l}\text { I thought that this entire exercise of involving freshmen } \\
\text { in senior design projects was well organized. }\end{array}$ & $\square$ & $\square$ & $\square$ \\
\hline h. & $\begin{array}{l}\text { Interacting with the freshmen has had a positive effect } \\
\text { on my grade in this course. }\end{array}$ & $\square$ & $\square$ & $\square$ & $\square$ \\
\hline i. & $\begin{array}{l}\text { The practice of using freshmen to interact with the } \\
\text { senior design groups should be continued. }\end{array}$ & $\square$ & $\square$ & $\square$ & $\square$ \\
\hline
\end{tabular}

\section{Prerequisites}

The prerequisites for Design of Fluid Thermal Systems are MECH 3331 Fluid Mechanics and MECH 4311 Heat Transfer.

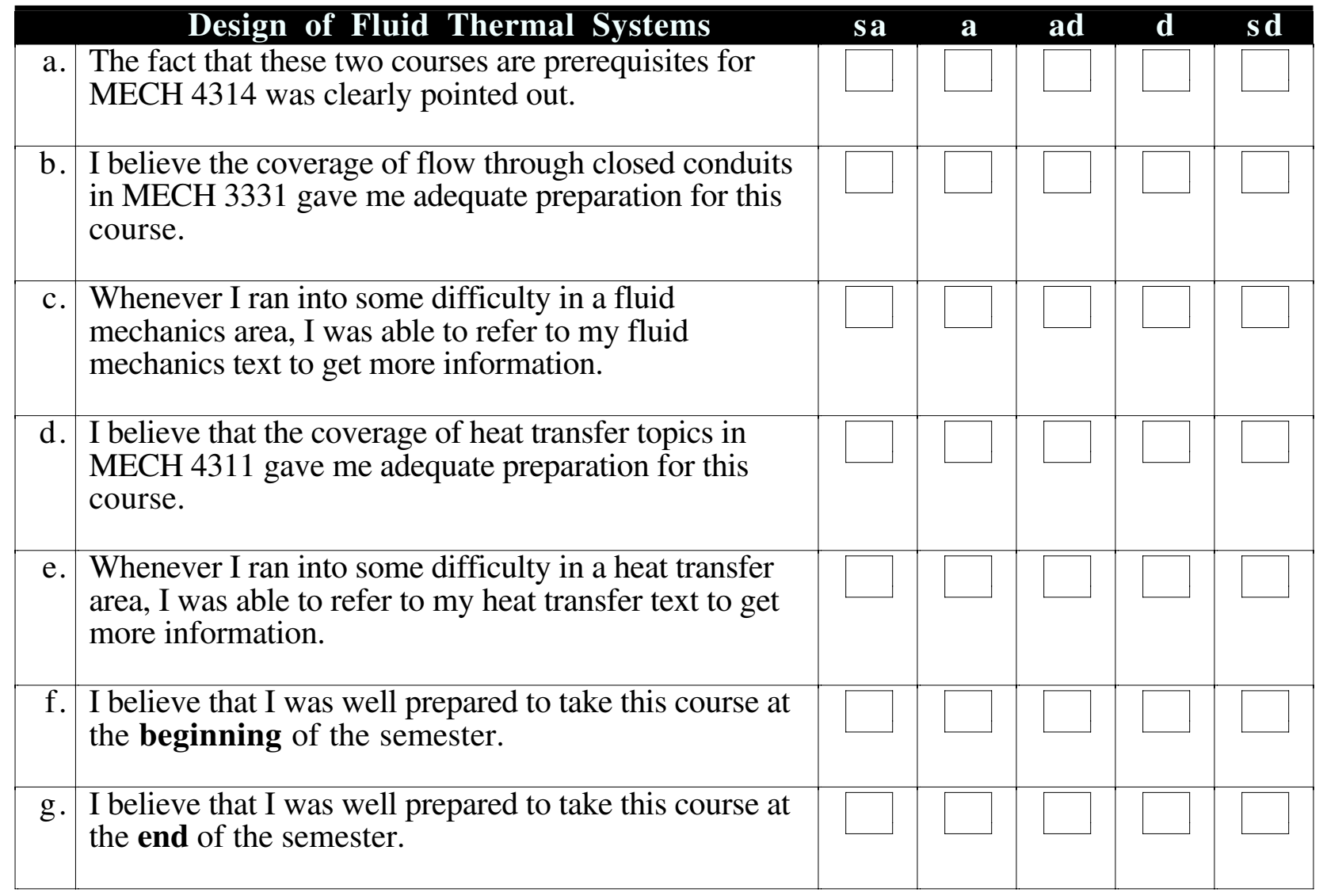

Terminal Design Experience Considerations

\section{Design of Fluid Thermal Systems}

a. We considered economic factors in the course of completing our design project. 


\begin{tabular}{|c|c|c|c|c|c|c|}
\hline $\mathrm{b}$. & $\begin{array}{l}\text { We considered environmental factors in the course } \\
\text { of completing our design project. }\end{array}$ & & . & & L & \\
\hline c. & $\begin{array}{l}\text { We considered sustainability (durability) in the } \\
\text { course of completing our design project. }\end{array}$ & & & & & \\
\hline d. & $\begin{array}{l}\text { We considered manufacturability in the course of } \\
\text { completing our design project. }\end{array}$ & & & & & \\
\hline e. & $\begin{array}{l}\text { We considered ethical issues in the course of } \\
\text { completing our design project. }\end{array}$ & & & & L & \\
\hline f. & $\begin{array}{l}\text { We considered health and safety factors in the } \\
\text { course of completing our design project. }\end{array}$ & & & & & \\
\hline g. & $\begin{array}{l}\text { We considered social issues in the course of } \\
\text { completing our design project. }\end{array}$ & & & & L & \\
\hline h. & $\begin{array}{l}\text { We considered political issues in the course of } \\
\text { completing our design project. }\end{array}$ & & & 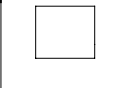 & 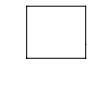 & \\
\hline i. & $\begin{array}{l}\text { We are assessed out—-too many assessment forms to } \\
\text { fill out this semester. }\end{array}$ & & & 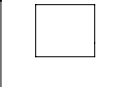 & \begin{tabular}{|l} 
\\
\end{tabular} & _ \\
\hline
\end{tabular}

\section{Technical Communication Skills}

Instructor Anna Phillips presented a short lecture on elements of technical presentations. Based on that lecture, rate the following statements:

\begin{tabular}{|c|c|c|c|c|c|c|}
\hline & Design of Fluid Thermal Systems & $\mathbf{s a}$ & $\mathbf{a}$ & ad & d & sd \\
\hline a. & $\begin{array}{l}\text { The short presentation on technical communication was } \\
\text { helpful for me in preparing for the final presentation. }\end{array}$ & & & & - & \\
\hline b. & $\begin{array}{l}\text { This presentation was linked to my coursework as an } \\
\text { engineering major. }\end{array}$ & & & & & \\
\hline c. & $\begin{array}{l}\text { This presentation prepared me for technical } \\
\text { presentations as a practicing engineer. }\end{array}$ & & - & & - & \\
\hline $\mathrm{d}$. & $\begin{array}{l}\text { I consulted either Ms. Phillips, Ms. Allen, or the } \\
\text { Writing Lab in preparing my final report/presentation. }\end{array}$ & & & & & \\
\hline
\end{tabular}




\section{Comments/Your Recommendations for Improvements}

Program Objectives

Competency Areas

Course Management

Interacting with Freshmen

Prerequisites

Technical Communication Skills

Your MOST favorite thing about this course

Your LEAST favorite thing about this course

Use additional sheets if necessary. 
Summary of Survey Results and Commentary

\section{MECH 4314 Design of Fluid Thermal Systems \\ "a thru p" GPA \\ Fall 2003}

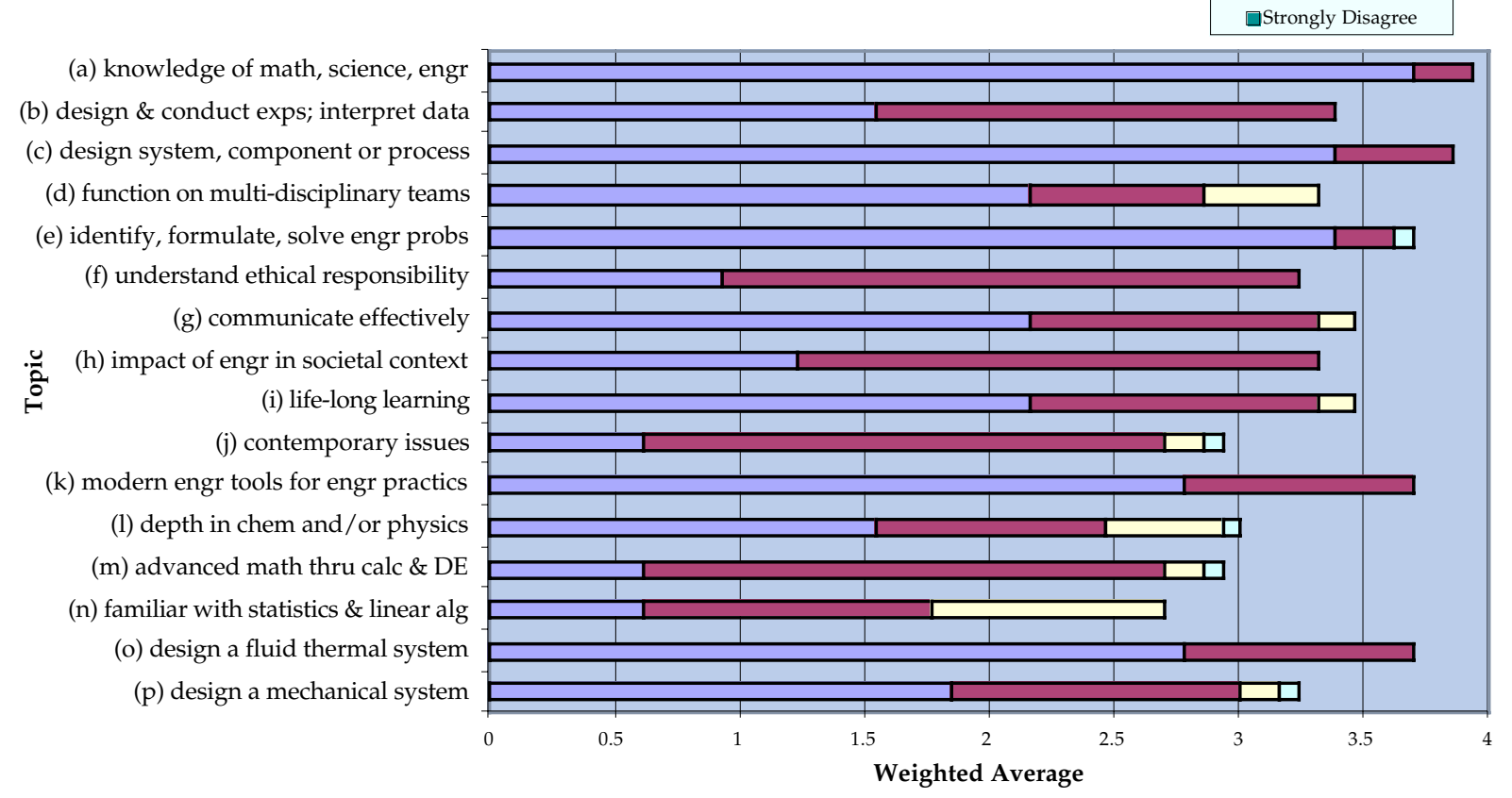

During the Fall 2003 semester, program outcomes "a through k" were stated for the students and they were asked to rate this course in each of these areas. In addition, program outcomes labeled as $1, \mathrm{~m}, \mathrm{n}, \mathrm{o}$, and $\mathrm{p}$ were included in the list. These items have been added in order to provide our department with a unique perspective on the education we offer.

The data obtained are presented in a weighted average scheme. Numbers obtained from the surveys were weighted to obtain something like a "GPA" for each entry. As indicated in the legend, a dark blue bar represents "Strongly Agree," red response signifies "Agree," yellow means "Neither Agree or Disagree," light blue signifies "Disagree," and green indicates "Strongly Disagree." The questions were worded such that a preponderance of dark blue and red is desirable.

The items that have blue and/or red bars long enough to reach or to extend past 3.0 (arbitrarily selected) or higher are believed to be those that are accomplished in this course. For example, consider the following item:

(o) An ability to work professionally in the thermal sciences area, including the ability to design a fluid thermal system

The chart shows that the weighted average of the student responses over 3.5; thus at the conclusion of the course, the students are confident in their ability "to work professionally in the thermal sciences area, including the ability to design a fluid thermal system." Table 1 (following) summarizes the responses. Targeted program outcomes are indicated as such. Items that did not meet the 3.0 criteria are flagged. 
TABLE 1. Summary of responses to items a through p. Targeted program outcomes are in green boldface type, and are noted in column 3. The targeted items that did not meet the 3.0 criteria are flagged in column 4.

\begin{tabular}{|c|c|c|c|}
\hline Item & Score & Targeted & Flag \\
\hline $\begin{array}{l}\text { (a) The ability to apply knowledge of math, science, \& } \\
\text { engineering to engineering problems }\end{array}$ & 3.9 & & \\
\hline $\begin{array}{l}\text { (b) An ability to design \& conduct experiments, and to analyze } \\
\text { \& interpret data }\end{array}$ & 3.4 & & \\
\hline $\begin{array}{l}\text { (c) An ability to design a system, component, or } \\
\text { process to meet a need }\end{array}$ & 3.8 & Yes & \\
\hline (d) An ability to function on multi-disciplinary teams & 2.8 & Yes & OOPS \\
\hline $\begin{array}{l}\text { (e) An ability to identify, formulate, and solve } \\
\text { engineering problems }\end{array}$ & 3.6 & Yes & \\
\hline (f) An understanding of professional ethical responsibility & 3.2 & & \\
\hline (g) An ability to communicate effectively & 3.3 & Yes & \\
\hline $\begin{array}{l}\text { (h) A broad education to understand the impact of engineering } \\
\text { in a societal context }\end{array}$ & 3.3 & & \\
\hline $\begin{array}{l}\text { (i) A recognition of the need for, and ability to engage in life- } \\
\text { long learning }\end{array}$ & 3.3 & & \\
\hline (j) A knowledge of contemporary issues & 2.7 & & \\
\hline $\begin{array}{l}\text { (k) An ability to use modern engineering tools for } \\
\text { the practice of engineering }\end{array}$ & 3.7 & Yes & \\
\hline $\begin{array}{l}\text { (l) Sufficient knowledge about chemistry and calculus-based } \\
\text { physics to have some depth in at least one of these areas }\end{array}$ & 2.5 & & \\
\hline $\begin{array}{l}\text { (m) An ability to apply advanced mathematics through } \\
\text { multivariate calculus and differential equations }\end{array}$ & 2.7 & & \\
\hline $\begin{array}{l}\text { (n) Enough background to be familiar with statistics and linear } \\
\text { algebra }\end{array}$ & 1.8 & & \\
\hline $\begin{array}{l}\text { (o) An ability to work professionally in the thermal } \\
\text { sciences area, including the ability to successfully } \\
\text { design a fluid thermal system }\end{array}$ & 3.7 & Yes & \\
\hline $\begin{array}{l}\text { (p) An ability to work professionally in the mechanics systems } \\
\text { area, including the ability to successfully design a mechanical } \\
\text { system }\end{array}$ & 3.0 & & \\
\hline
\end{tabular}


The objective here is to determine which of the "a through $\mathrm{p}$ " issues were addressed in this course, and to identify those items that were not. Item $d$ is a targeted program objective, in which the student is to gain an ability to function on multi-disciplinary teams. Item d earned a score of 2.8 which is less than the arbitrarily selected 3.0. At this time, it is felt that this result warrants no positive action in an effort to make an improvement for Fall 2004 because:

- The cutoff at 3.0 is arbitrarily selected.

- The 2.8 score is only $7 \%$ less than the 3.0 target.

- The score in the two previous years for Item $\mathrm{d}$ is 3.7 (Fall 01) and 3.5 (Fall 02).

\section{MECH 4314 Design of Fluid Thermal Systems Competency Areas-Fall 2003}

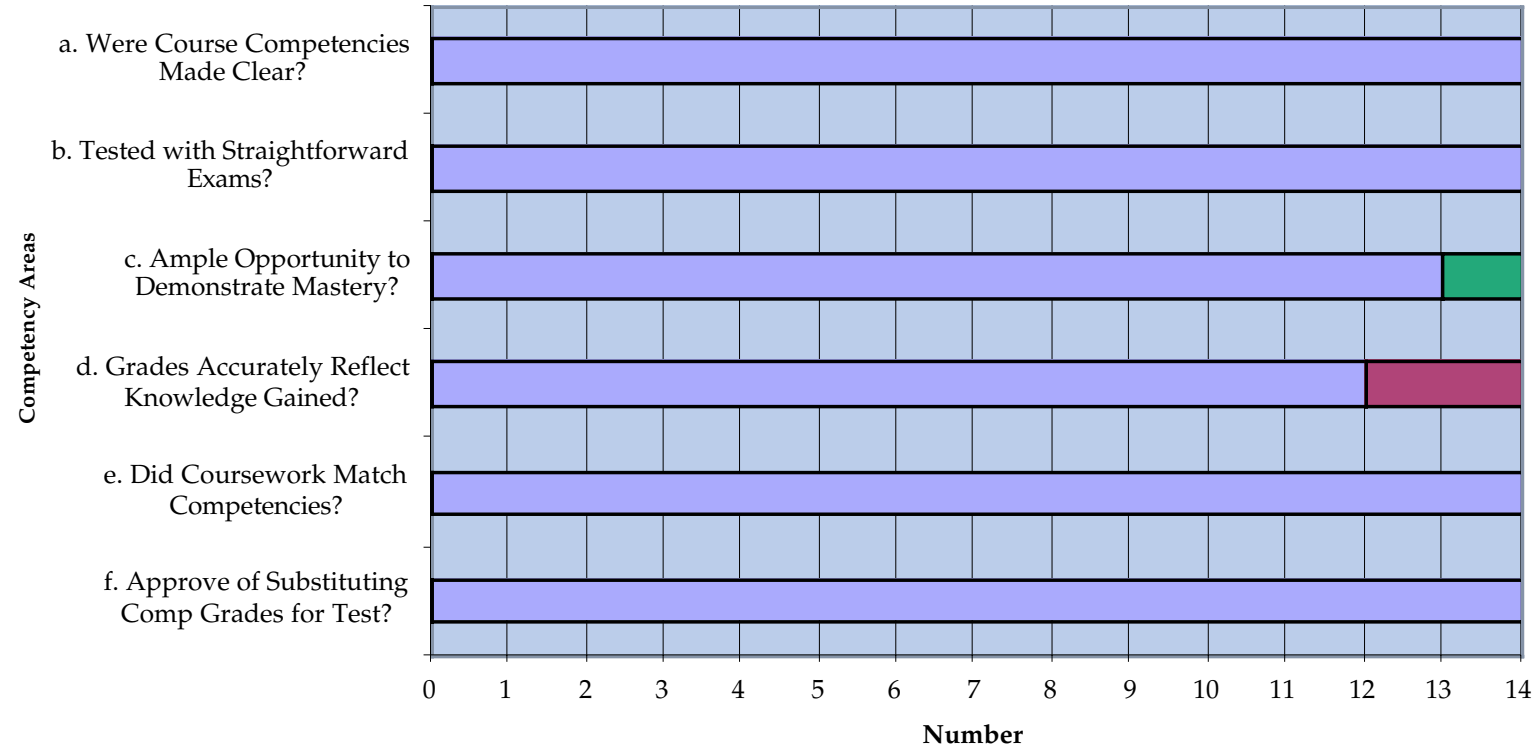

The preceding graph addresses Competency Areas that have been identified. For MECH 4314 Design of Fluid Thermal Systems, these are listed below. The colors used in the legend are as described earlier, with dark blue meaning "Strongly Agree" and red meaning "Agree." A preponderance of these colors shows that the Competency Areas were made clear, that students were tested regularly and frequently on them, and that student grades accurately reflect performance in these Competency Areas:

1. Demonstrate the ability to solve practical pipe flow problems: given a piping system, find the pressure drop.

2. Demonstrate the ability to solve practical pipe flow problems: given minimal piping system information, determine the pipe diameter that will minimize the initial and operating costs for an installation.

3. Demonstrate the ability to size a pump for a given piping system and to select an operating configuration to avoid pump cavitation. 
4. Demonstrate the ability to analyze a heat exchanger: given two flow streams, calculate expected outlet temperatures.

5. Demonstrate the ability to function as a member of a design team. [This is evaluated by performance as part of a group while solving the semester long design project.]

\section{MECH 4314 Design of Fluid Thermal Systems Course Management-Fall 2003}
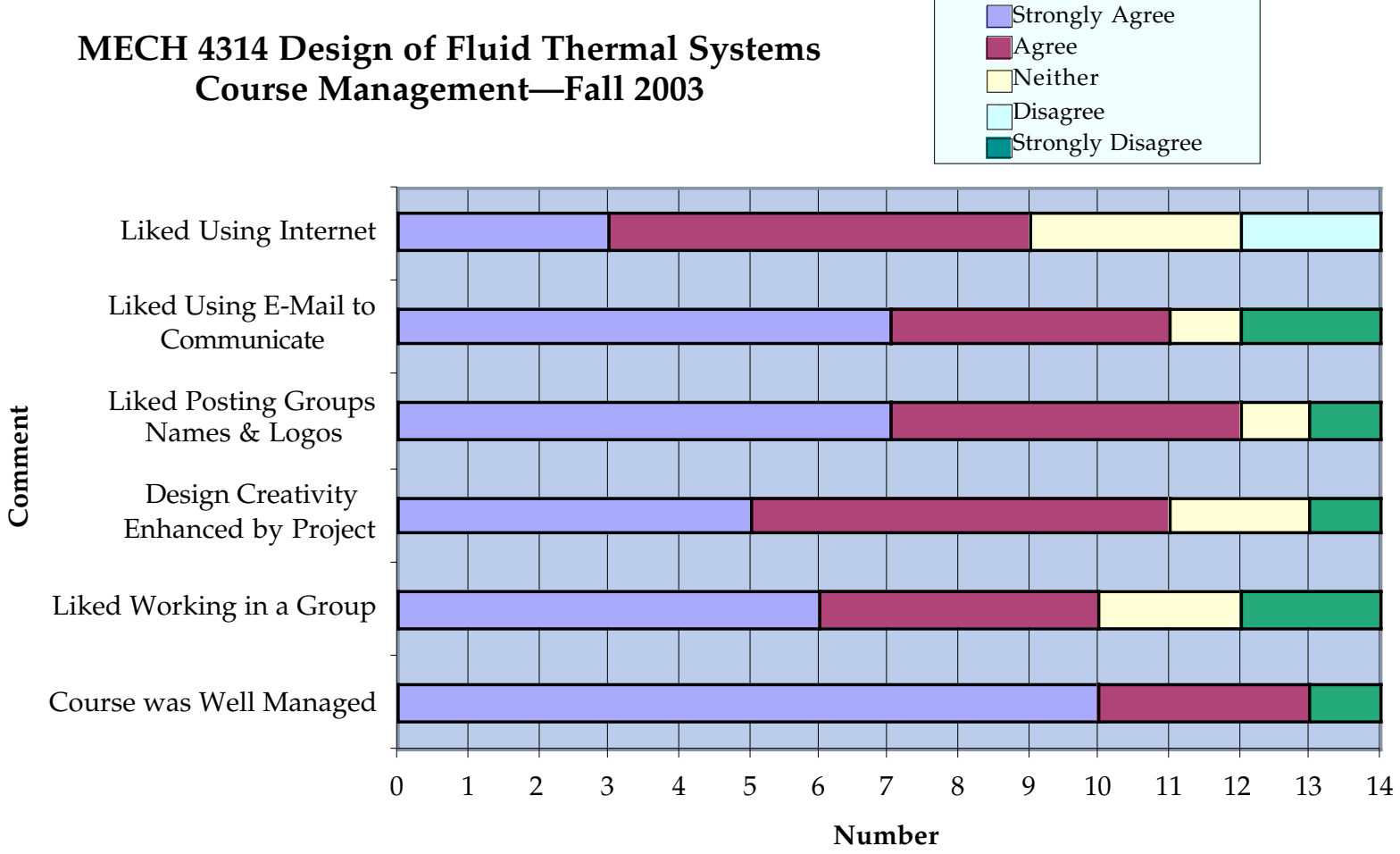

The preceding chart presents student opinions regarding quality of instruction and how well the course was managed. As indicated in the legend, a dark blue bar represents "Strongly Agree," red response signifies "Agree," yellow means "Neither Agree or Disagree," light blue signifies "Disagree," and green indicates "Strongly Disagree." The questions were worded such that a preponderance of dark blue and red is desirable.

The internet was used extensively in this course. Background information for projects was provided at a web site, as were names of students in each design group, reference information, and a calendar. The calendar was used to give homework assignments to students. Each student group selected a company name and drew up a company logo. These were also posted on the class web site. Communication between the instructor and the students was accomplished via e-mail.

There appears to be no areas that need special attention to make improvements. 


\section{MECH 4314 Design of Fluid Thermal Systems Interacting with Freshmen-Fall 2003}

Strongly Agree

Agree

Neutral

Disagree

Strongly Disagree

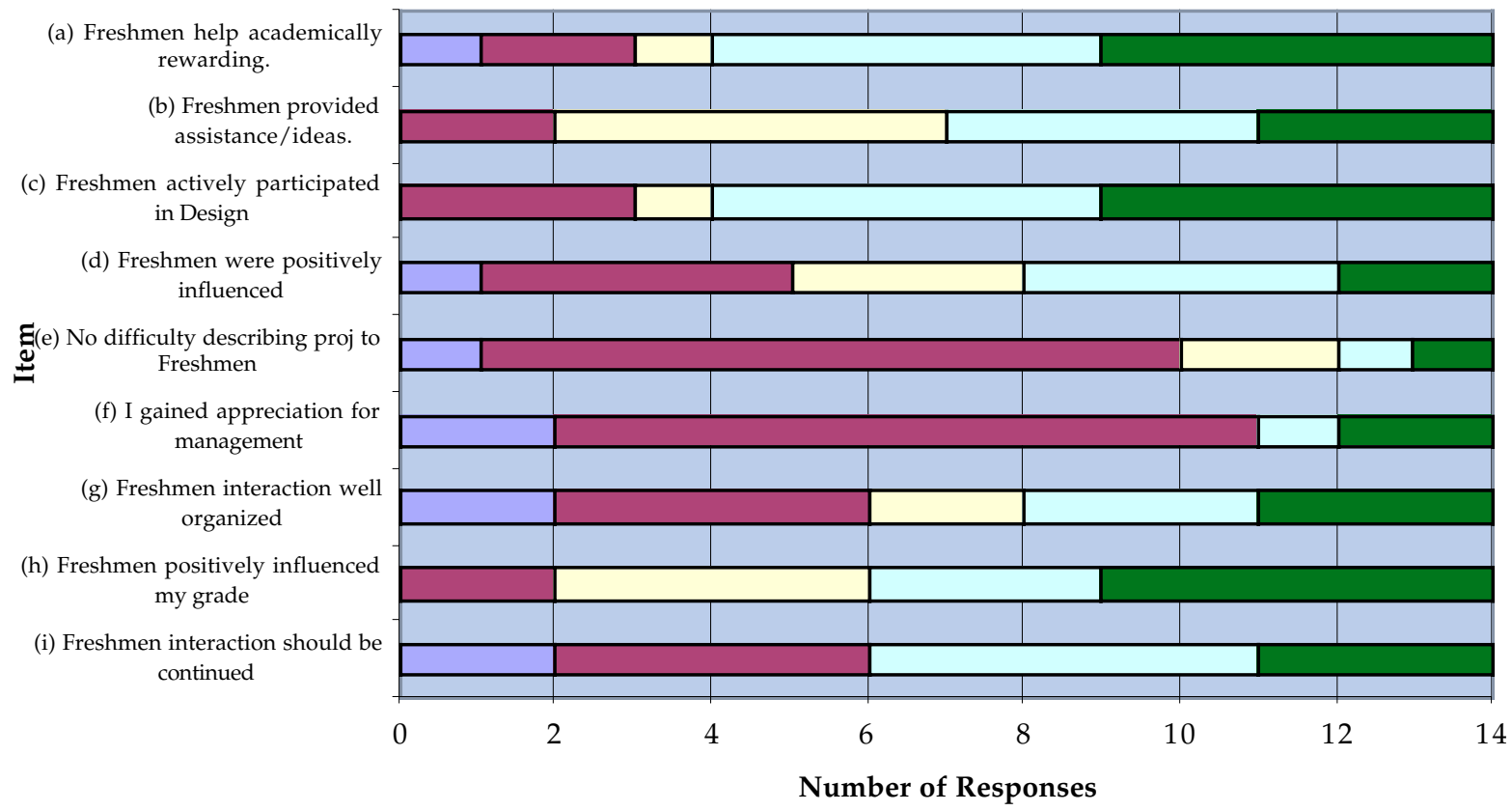

During Fall 01, a new experiment was conducted in the Design of Fluid Thermal Systems course. Freshmen that were enrolled in the Introduction to Mechanical Engineering course (MECH 1307) were required to interact with the seniors in the Design course. The seniors were divided into design groups that function as small consulting companies. The freshmen were like "co op" students who worked for these companies. Freshmen were given assignments by the senior design groups. These assignments varied, depending on the project that was being worked on by the seniors. This practice was continued in Fall 02 and again in Fall 03. After the students were surveyed, an assessment of the results was obtained, and subsequently various modifications to this practice were made in order to improve the freshmen-senior interaction.

The preceding graph presents student opinions regarding this relatively new practice, which is now in its third cycle. As indicated in the legend, a dark blue response means "Strongly Agree," etc. The response to Item a indicates that interacting with freshmen was not particularly rewarding for the seniors. In previous years, the freshmen-senior interaction received more favorable reviews, but Fall 03 was different. The freshmen to senior ratio was unusually large in Fall 03, and managing a huge number of freshmen required a lot of time by the seniors, and it is believed that this was the cause of the seemingly unpopular practice in Fall 03.

The response to Item a indicates that interacting with freshmen was not particularly rewarding for 10 out of 14 seniors, and only 3 of 14 thought it was. One student neither agreed nor disagreed with this statement. Seniors in general did not feel that their grades were improved by the presence of freshmen on their design teams.

Item $\mathrm{b}$ shows that 2 of 14 seniors believed that freshmen were able to provide some assistance to the overall design effort. Every group was able to have the freshmen work productively with them in some capacity, however. 
Item c shows that 3 of 14 seniors strongly agreed or agreed that the freshmen actively participated in the design process, but 10 of 14 did not. It is acknowledged that freshmen participation in the actual design phase is rather limited, due to their inexperience with engineering fundamentals. The goal of having the freshmen gain an appreciation for engineering design, however, is believed to have been met.

One of the objectives of building this collaboration was a desire to increase the retention rate of the freshmen by involving them with the seniors in design work. Item d shows that 5 of 14 seniors perceived that they had a positive influence on making freshmen want to stay in engineering. Three seniors had no opinion, and 6 seniors disagreed or strongly disagreed with this statement.

Item e indicates that 10 of 14 seniors had little difficulty in describing their projects to the freshmen. Developing the student's ability to communicate technical ideas to a non-technical audience is one of the seldom mentioned objectives in this course. This is one of the stronger outcomes of the collaboration.

Item $\mathrm{f}$ shows that 11 of 14 seniors gained some appreciation for the effort involved in managing engineers, while 2 did not.

In Fall of 2001, the seniors felt that this venture was not well organized. After making several changes for Fall 2002 and Fall 2003, we see 6 seniors felt that this project was well organized, and 6 of 14 felt it was not. The students were thus evenly divided on this issue, although there is still room for improvement over last year.

Item $\mathrm{h}$ shows that 2 of 14 seniors felt that interacting with the freshmen did have a positive effect on the grades received by the seniors. Eight disagreed, and 4 were neutral.

Item $i$ asks the seniors about continuing the practice of involving freshmen in senior design projects, and the majority of the responses ( 8 of 14) are negative. Only 6 of 14 thought it should be continued.

The plan is to continue this project for one more cycle, so that freshmen in Fall 01 who served as co op students will be seniors in Fall 04. This uniquely experienced group will help provide assessment data that will determine whether the freshmen senior collaboration should continue. Also, it is hoped that the unusual numerical imbalance of Fall 2003 will not be repeated next year.

Consequently, there will be no areas that need special attention to make improvements. However, additional structure will be added in MECH 1307 (the freshman class) to more closely track freshmen activities in an effort to improve the value of this experience for both freshmen and seniors. 

MECH 4314 Design of Fluid Thermal Systems
Prerequisites-Fall 2003
Strongly Agree

Agree

Neutral

Disagree

Strongly Disagree

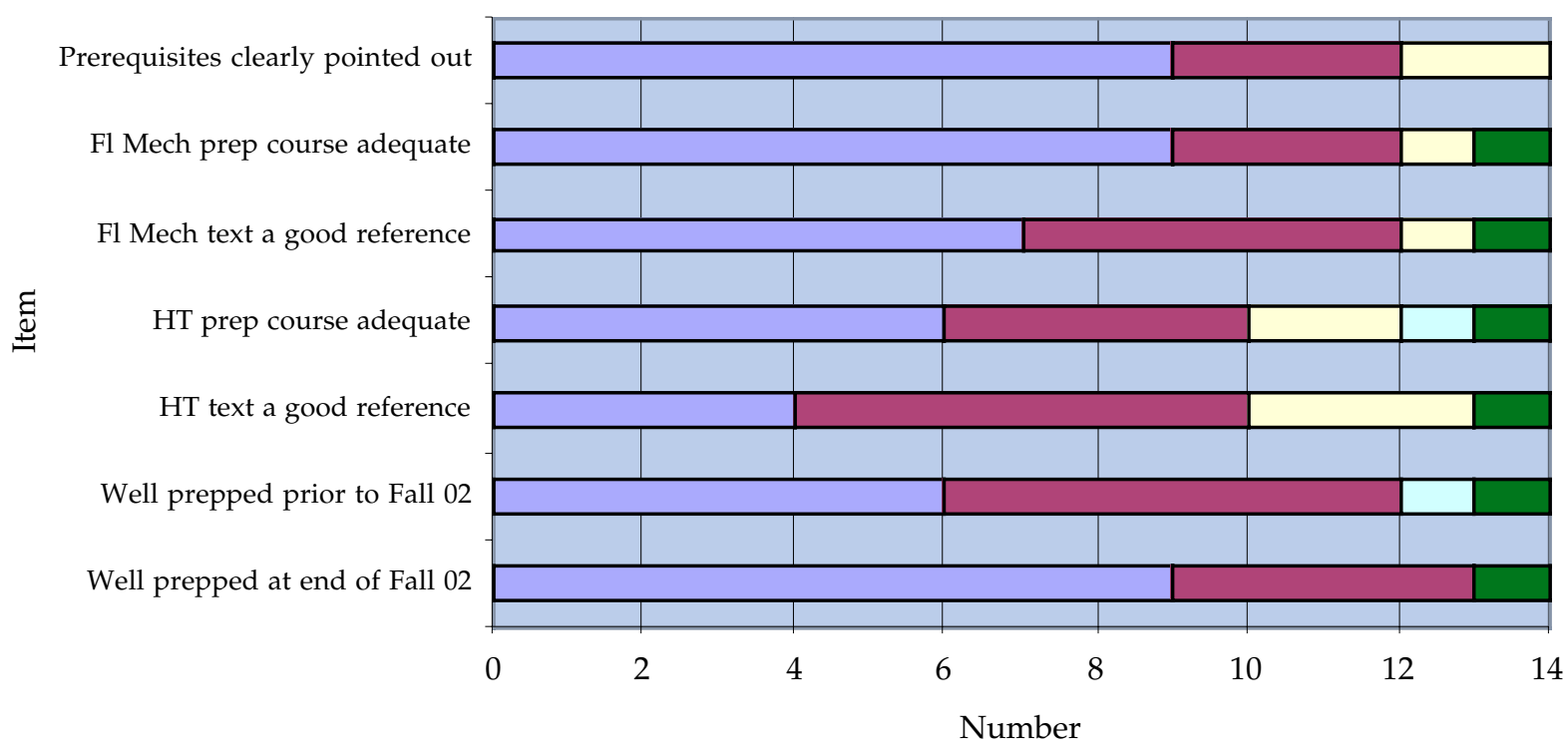

The prerequisites for Design of Fluid Thermal Systems are fluid mechanics (MECH 3331) and heat transfer (MECH 4311). Many students are often not prepared well enough to succeed in the Design course without a significant amount of time spent on review of these topics. Consequently, a survey was taken that was centered about the prerequisites.

The preceding graph shows student responses to questions about the fluid mechanics and the heat transfer course. A preponderance of dark blue and red are considered good. As shown, the prerequisites were clearly pointed out to the students; this was done on the first day of classes.

The fluid mechanics course and textbook both appear adequate. The heat transfer course and textbook both appear to be adequate with regard to properly preparing students for the Design course, although in Fall 03, several of the students were admitted to the Design course without heat transfer. This was done because the heat transfer course was canceled in the preceding semester due to low enrollment. For the Design course, this practice meant that more time was spent in preparing the students to solve heat transfer problems that are indigenous to the course.

There appears to be no areas that need special attention to make improvements.

\section{Design Considerations/Constraints}

Various issues exist with regard to the design projects themselves. These considerations include the following:

Were economic factors considered in the course of completing the design project?

Were environmental factors considered in the course of completing the design project? 
Was sustainability considered in the course of completing the design project?

Was manufacturability considered in the course of completing the design project?

Were ethical issues considered in the course of completing the design project?

Were health and safety factors considered in the course of completing the design project?

Were social issues considered in the course of completing the design project?

Were political issues considered in the course of completing the design project.

The students were surveyed about these issues and factors. Each group worked on a different project, and so the responses are kept separate by group and by project. Following now are project descriptions and student responses to the considerations listed above.

\section{A Heating System for a Tank Car (5 engineers)}

Conventional railroad tank cars are used to transport glucose from a supplier to a company that makes jellies, jams, and preserves. Upon arrival, the glucose in the tank car must be heated to make it easier to pump out. Heating can be done by using steam or electricity. These two methods are compared in this project.

If the glucose is to be heated with steam, then the tank car must be manufactured with tubes inside. When the car is filled with glucose, the tubes will be completely submerged. An external steam source is then connected to the tube inlet at the car, and steam is pumped inside. The tubes must be completely sealed so steam cannot leak inside.

If the glucose is to be heated electrically, then electric resistance heaters are to be installed in the tank car at the time it is manufactured. The resistance heaters will be submerged within the glucose. An external power supply is then connected to the heaters and the glucose is heated.

To be designed, selected, or determined:

1. A layout for the steam tubes within the car.

2. A tube diameter.

3. Materials to be used for the tubing.

4. Steam flow rate and inlet temperature. (After passing through, should the steam be discharged to atmosphere, or collected and reheated?)

5. Cost of the steam heating system (tubing cost, labor associated with fluid tight installation, and operating costs).

6. A layout or positioning of the immersion heater(s).

7. Electric power required.

8. Cost of electric heating system (heating, labor associated with installation, and operating costs).

9. The optimum temperature at which glucose should be maintained, as dictated by minimum cost analysis.

10. Perform all calculations for a conventional 40-foot tank car. Should the tank be insulated?

What are its exact dimensions? 


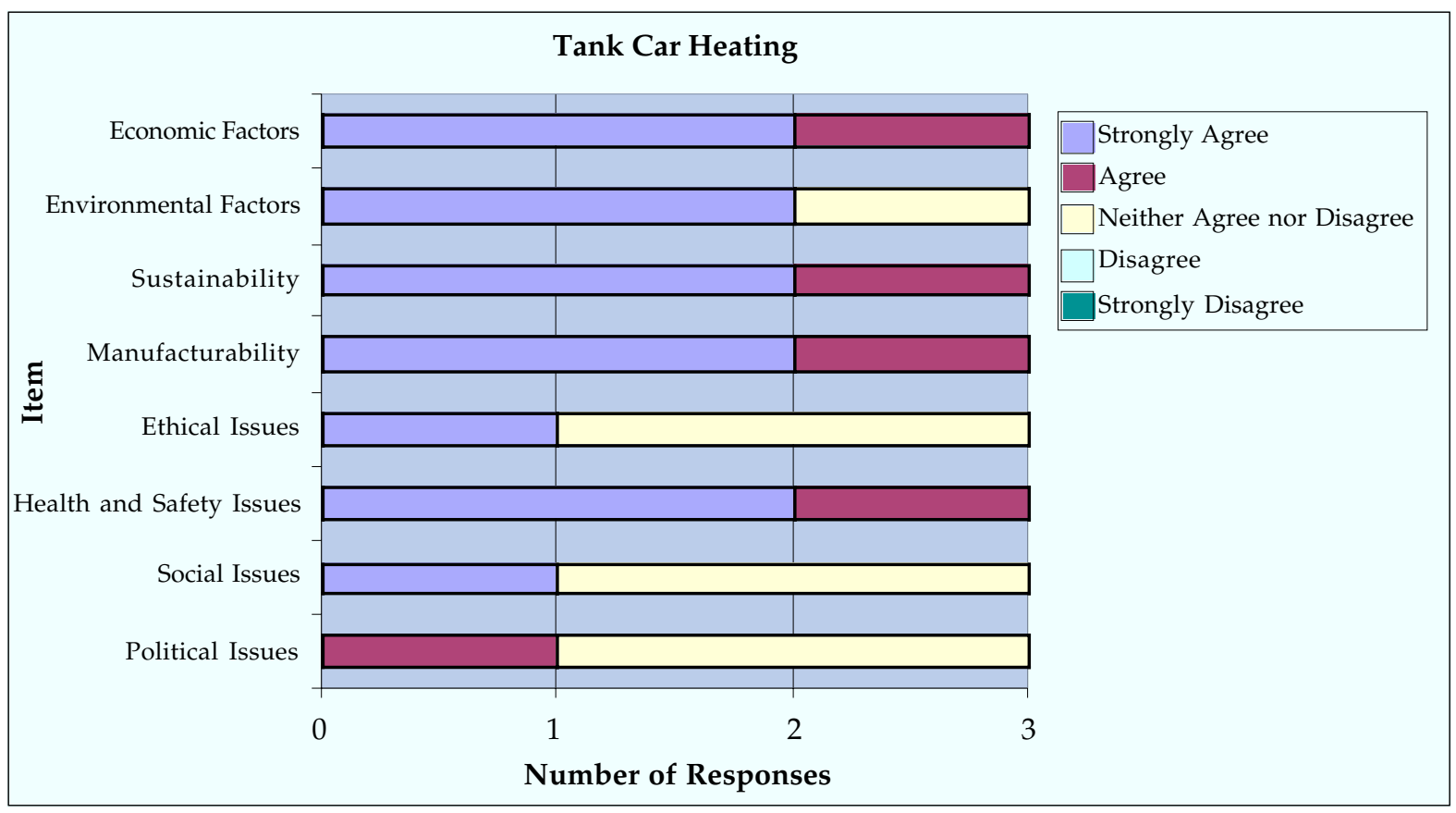

Factors the students thought were considered during the completion of the design project:

Economic factors

Environmental factors

Sustainability

Manufacturability

Health and Safety issues

Not believed to have been given significant consideration:

Ethical issues

Social issues

Political issues

\section{Amusement Park Water Slide (5 engineers)}

It is desired to construct a water slide in an amusement park. People of all ages and body shapes will climb stairs or a ramp to the top of the slide and ride down on a rubber or rubber-substitute mat. One acre of land can be devoted to the slide and its associated operation (e.g., ticket selling booth, steps or ramp).

To be designed, selected, or determined:

1. Slide height, width, path, and material of construction.

2. Support structure and material of construction, including ground support.

3. "Catch" basin or method for individuals coming off the slide at the bottom.

4. Pump size, type, and location.

5. Piping, piping material, and routing.

6. Additives required to maintain the water (consider also that water may freeze during winter months).

7. Mat size, material, color, and number to be ordered.

8. Layout of the slide and its mode of operation on the acre of land. 
9. Total cost of the slide, its expected life, and an estimate of the portion of the cost of a ticket that will cover this cost over the expected life.

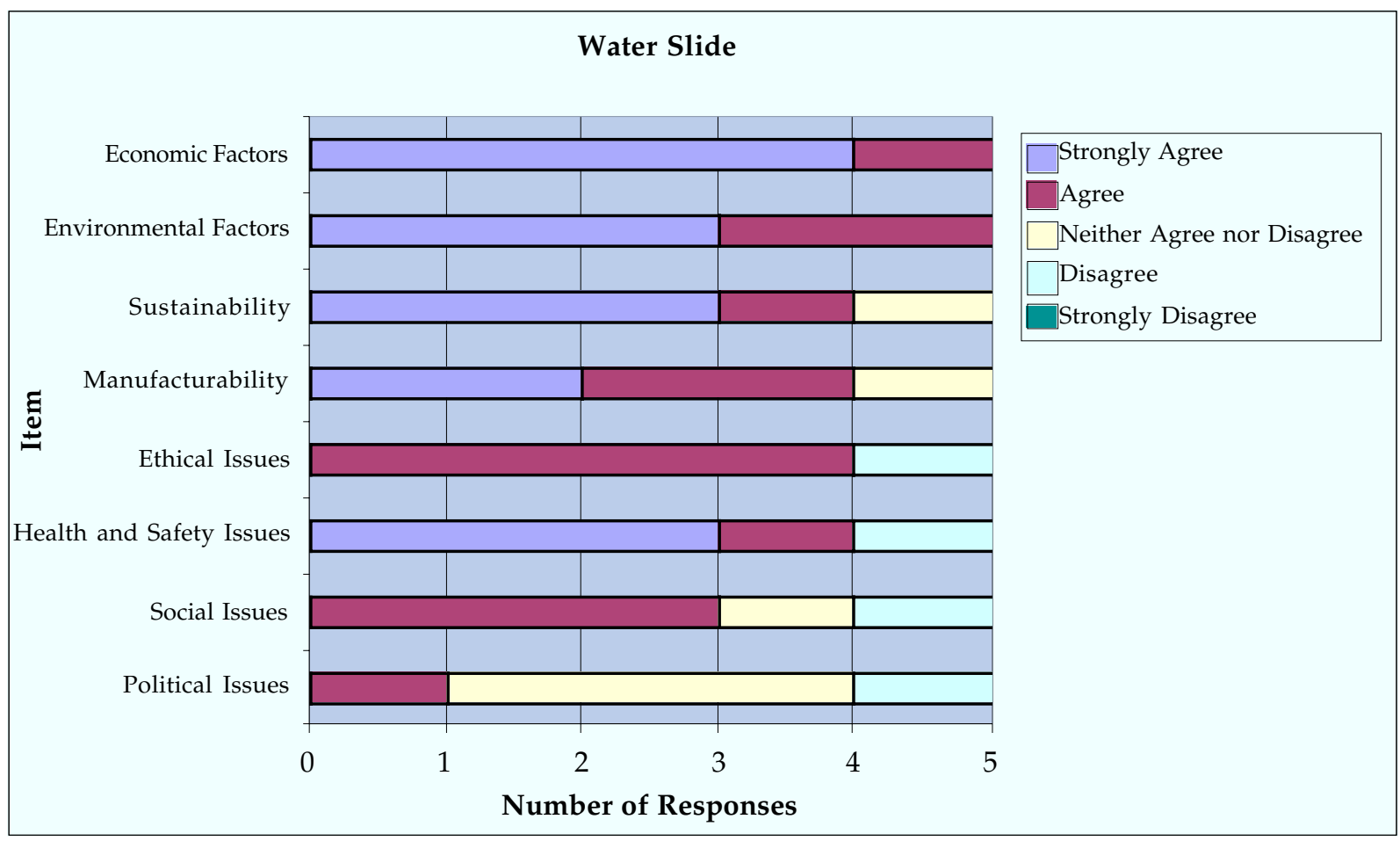

Factors the students thought were considered during the completion of the design project:

Economic factors

Environmental factors

Sustainability

Ethical issues

Manufacturability

Health and Safety issues

Social issues

Not believed to have been given significant consideration:

Political issues

\section{A Toy Vertical Wind Tunnel ${ }^{\dagger}$ (4 engineers)}

The objective of this project is to design a vertical wind tunnel (VWT) that can be used as a toy. A company that manufactures toys wishes to market a vertical wind tunnel to use with their other products such as those advertised as "hero action figures." The action figure would be placed on a starting position, air would be directed upward to move the action figure to a maximum height of 6 $\mathrm{ft}$, and then the air is turned off. The action figure would then begin falling. A parachute would open and the figure would be brought slowly to the ground. (This project deals with designing only the vertical wind tunnel. However, you will be asked to make specifications on the weight, volume and shape of the hero action figure.)

Thus the design would have the following constraints; the VWT should: 
- Be as small as possible.

- Present NO safety hazards, as it is to be used by children.

- Be operable outside in cold weather as well as in warm weather.

- Not make excessive noise (if possible)

- Offer the operator a fine adjustment of air velocity.

- Not be costly.

- Be maintenance free for at least one year.

- Be able to levitate an action figure to a height of 6 feet.

To be designed, selected, or determined:

1. Design a device that can used as a vertical wind tunnel to levitate a hero action figure. Does the action figure have to be oriented in a certain way; i.e., with arms and legs extended as in a skydiving configuration?

2. Select a fan for moving air through the system. What type of fan is better suited for this purpose: a high flow rate fan or a high pressure fan? Prove that your system will work as designed by using engineering calculations.

3 . What velocity is required to move the action figure? How does velocity change with height as the air moves upward?

4. What are the safety issues that must be addressed in your design? Show what can be done to minimize the safety hazards.

5. How large must the unit be?

6. Determine the cost to build the device.

7. Determine how much can be charged to the consumer for your toy vertical wind tunnel.

†Submitted by Professor Julie Mathis.

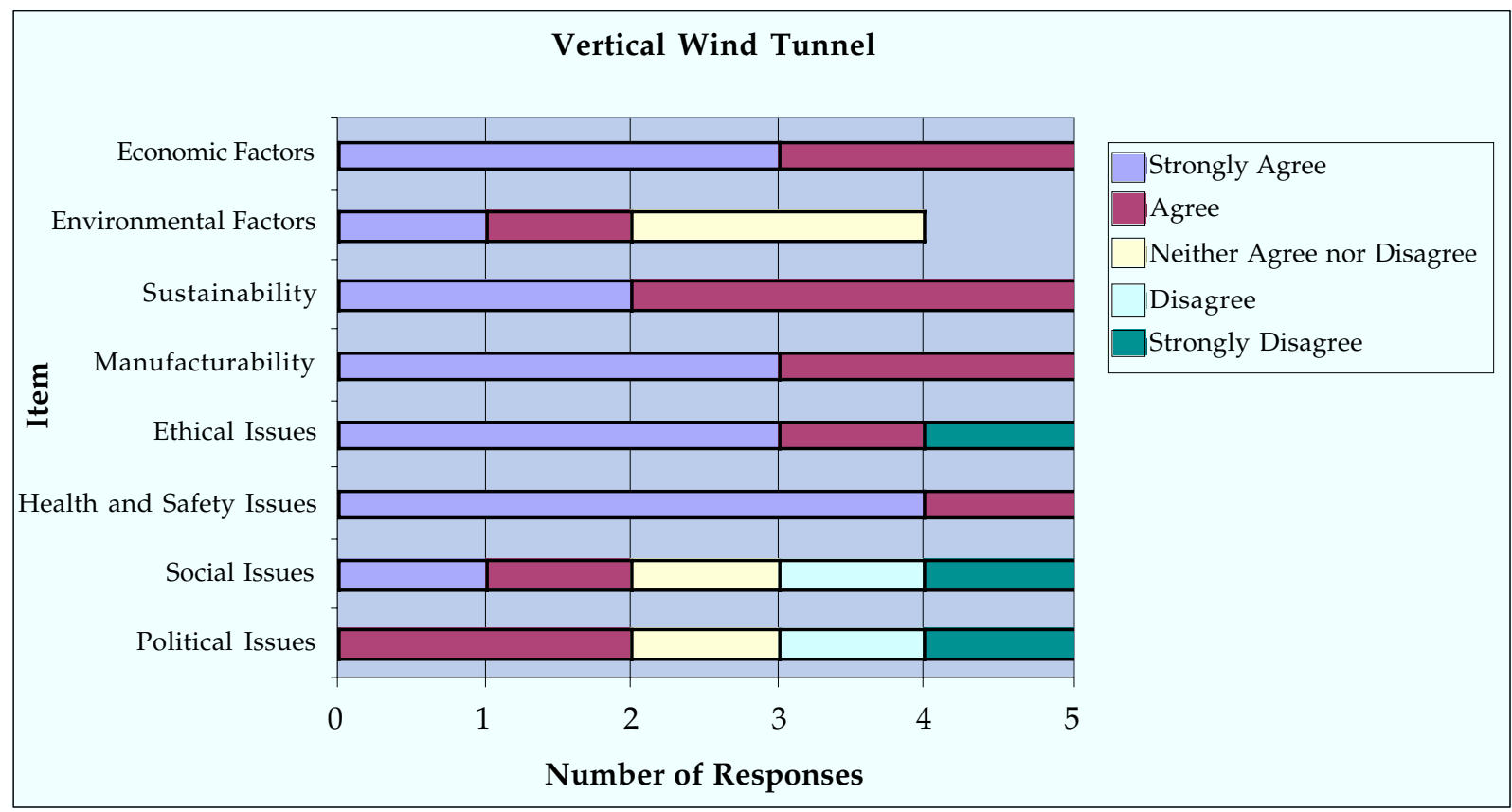

Factors the students thought were considered during the completion of the design project:

Economic factors

Sustainability

Manufacturability 
Ethical issues

Health and Safety issues

Not believed to have been given significant consideration:

Environmental factors

Social issues

Political issues

Obviously, student opinions regarding these constraints can differ significantly from the opinion of the instructor. The results of these surveys are summarized in the Table 2. Shown are checkmarks indicating student opinions, summarized from the preceding paragraphs and charts. Also shown are the instructor's opinions regarding these constraints.

TABLE 2. Capstone fluid thermal system design experience information about various considerations. Student opinions are denoted as “ $\sqrt{ }$," while the instructor's opinions are marked with an "X."

\begin{tabular}{|c|c|c|c|c|c|}
\hline & \multicolumn{5}{|c|}{ Project Title } \\
\hline Design Constraints & $\begin{array}{c}\text { Tank Car } \\
\text { Heating }\end{array}$ & $\begin{array}{l}\text { Am } \\
\text { Par }\end{array}$ & $\begin{array}{l}\text { Water } \\
\text { Water } \\
\text { de }\end{array}$ & $\begin{array}{l}\text { Vert } \\
\text { Winc }\end{array}$ & $\begin{array}{l}\text { I Toy } \\
\text { unnel }\end{array}$ \\
\hline Economic factors & $\mathrm{X}$ & $\sqrt{ }$ & $\mathrm{X}$ & $\sqrt{ }$ & $\mathrm{X}$ \\
\hline Environmental factors & $\mathrm{X}$ & $\sqrt{ }$ & $\mathrm{X}$ & & \\
\hline Sustainability & $\mathrm{X}$ & $\sqrt{ }$ & $\mathrm{X}$ & $\sqrt{ }$ & $\mathrm{X}$ \\
\hline Manufacturability & $\mathrm{X}$ & $\sqrt{ }$ & $\mathrm{X}$ & $\sqrt{ }$ & $\mathrm{X}$ \\
\hline Ethical issues & & $\sqrt{ }$ & $\mathrm{X}$ & $\sqrt{ }$ & \\
\hline Health \& safety factors & $\mathrm{X}$ & $\sqrt{ }$ & $\mathrm{X}$ & $\sqrt{ }$ & $\mathrm{X}$ \\
\hline Social issues & & $\sqrt{ }$ & $\mathrm{X}$ & & \\
\hline Political Issues & & & & & \\
\hline
\end{tabular}

\section{Student Comments}

\section{Regarding Program Objectives}

- Good

- Very practical and well designed course.

- Very realistic

- I believe that there should be individual groups because there are some lazy asses that don't do what they are asked.

\section{Regarding Competency Areas}

- I like the format of the tests

- Competencies relate very well with real world problems.

- Serious

- Good idea, encourage studying 


\section{Regarding Course Management}

- Good

- I like being able to go to the web for information, but I would have liked the instructor to give all info in class too.

- Great!!!

- Exceptional (web, access... .)

\section{Regarding Interacting with Freshmen}

- Since the Freshmen have not taken any of the necessary courses, their input on design is at most limited.

- Could be better. Too many freshmen for each member of design team. A more one on one Freshman design project would do more good.

- It is a good idea, but we have so much to do already and it's extra work to think of stuff for them to do. I think a class like senior seminar should be restructured when seniors can assist freshmen on a smaller project.

- This took valuable time that could have been used working on our project. There should be a diesng class for freshmen. They are in charge, and we get class credit for helping them.

- These design projects require too much prior knowledge to fully include the freshmen. The group of freshmen was also too large.

- Bring them in a few weeks later

- It would be better if the freshmen had projects that they were capable of doing and the seniors were used as advisors.

- The freshmen's grade should be better reflected in their participation.

- Needs better structure, most freshmen never showed up or did nothiing and left all the work to those who showed up. The few that worked did very little, but did help a bit on the research part of the project.

\section{Regarding Prerequisites}

- I was weak in H.T.

- I can't complain. The Heat Transfer was waived for me and I don't think it caused me any difficulty in class, but my design project was considerably difficult.

- I was lacking in H.T.

- I had heat transfer over the summer and it was a bit rushed, so I didn't get all I needed out of the class.

\section{Regarding Technical Communication Skills}

A smaller (additional) singular report would be nice for individuals.

\section{Regarding MOST favorite thing about the course}

TS (The ability to bring humor into the classroom and still learn.)

Show and Tells.

The instructor's enthusiasm to teach.

Format of competencies. 
Friendly classroom atmosphere.

The entire class minus the homework.

Learning about fluid thermo systems while having fun.

Rolling dice.

Learning to actually design and engineer different projects.

Learning to design a piping system layout including pump sizing.

Relaxed class atmosphere; Dr. J was available for questions; challenging work load; comp quizzes couting for test I grade.

The focus of the course paralleled my job almost perfectly. I enjoyed the entire class until the heat exchanger section.

Lecture period; plaing homeworks on board; show and tell; all other methods of ensuring all student participation, involvement; rolling for decisions $\mathrm{OK}$; design project.

\section{Regarding LEAST favorite thing about the course}

Working with the freshmen interns.

Spending hours on homework that isn't collected.

Meeting 5 days a week.

Homework due the next day. Homework should be due on MWF.

Too much homework.

Homework that is due the day after being assigned; working with the freshmen.

Homework.

Interns.

Having to come to class almost 5 days a week.

Derivations of formulas - such as some of the homework problems.

Homework being due next class; working with freshmen students.

Heat exchangers (long and drawn out). Dr. Janna did a great job making it interesting.

Best homework \& most efforts not graded.

Freshmen brought in too soon.

\section{List of Action Items and Disposition}

The only area that needs attention is the freshmen senior interaction, and that will not be modified until after Fall 2004 (for reasons stated earlier).

\begin{tabular}{|l|l|l|}
\hline \multicolumn{1}{|c|}{ Date } & \multicolumn{1}{c|}{ Activity } & \multicolumn{1}{c|}{ Completed } \\
\hline $\begin{array}{l}\text { December 2003 } \\
\text { (end of Fall semester) }\end{array}$ & $\begin{array}{l}\text { Administered survey instrument to all students } \\
\text { completing the course }\end{array}$ & December 2003 \\
\hline January 2003 & Began work on final report. & TBA; continuing. \\
\hline
\end{tabular}

Estimate of Time Spent on the Activities of this Process

\begin{tabular}{|l|r|}
\cline { 2 - 3 } \multicolumn{1}{l|}{} & \multicolumn{1}{|c|}{} \\
\hline Modifying survey. & 1 hours \\
\hline Preparing Results (compiling completed surveys, preparing graphs). & 8 hours \\
\hline Preparing report (first draft). & 20 hours \\
\hline Proofreading report and preparing second draft & 2 hours \\
\hline Total & 31 hours \\
\hline
\end{tabular}




\section{Biographical Information}

WILLIAM S. JANNA joined the faculty of The University of Memphis in 1987 as Chair of the Department of Mechanical Engineering. He was formerly Associate Dean for Graduate Studies and Research in the Herff College of Engineering. His research interests include boundary layer methods of solution for various engineering problems, and modeling the melting of ice objects of various shapes. He is the author of three textbooks, a member of ASEE and of ASME. He teaches continuing education courses in the area of piping systems and in heat exchanger design and selection, for ASME. Dr. Janna received a B.S. degree, an M.S.M.E. and a Ph.D. from the University of Toledo.

JOHN I. HOCHSTEIN joined the faculty of The University of Memphis in 1991 and currently holds the position of Chair of the Department of Mechanical Engineering. In addition to engineering education, his research interests include simulation of micro gravity processes and computational modeling of fluid flows with free surfaces. He is a co-author of a textbook, Fundamentals of Fluid Mechanics, with P. Gerhart and R. Gross and is an Associate Fellow of AIAA. Dr. Hochstein received a B.E. degree from the Stevens Institute of Technology, an M.S.M.E. degree from The Pennsylvania State University, and a Ph.D. from The University of Akron. 